\title{
Concomitant occurrence of fusion and eagle's talon in a single patient
}

\author{
Pratik B Kariya, ${ }^{1}$ Sweta Singh, ${ }^{2}$ Rachappa Mallikarjuna, ${ }^{3}$ Kapil Dagrus ${ }^{4}$
}

${ }^{1}$ Department of Pedodontics and Preventive Dentistry, K M Shah Dental College and Hospital, Vadodara, Gujarat, India

${ }^{2}$ Department of Public Health Dentistry, K M Shah Dental

College and Hospital, Vadodara, Gujarat, India ${ }^{3}$ Department of Pedodontics and Preventive Dentistry, Child Dental Health, Oman Dental College, Muscat, Oman ${ }^{4}$ Department of Oral Pathology, K M Shah Dental College, Vadodara, Gujarat, India

\section{Correspondence to} Dr Rachappa Mallikarjuna, mmrachappa@gmail.com

Accepted 23 May 2015

\section{(Q) CrossMark}

To cite: Kariya PB, Singh S,
Mallikarjuna R, et al. BMJ
Case Rep Published online:
[please include Day Month
Year] doi:10.1136/bcr-2015-
210592

To cite: Kariya $\mathrm{PB}$, Singh $\mathrm{S}$, Mallikarjuna $\mathrm{R}$, et al. BMJ Case Rep Published online: Year] doi:10.1136/bcr-2015210592

\section{DESCRIPTION}

Variations of size, shape, number, colour and development of teeth are referred to as dental anomalies of the teeth. The precise aetiology responsible for these developmental anomalies still remains unknown.

Fusion is generally regarded as a union of two or more hard tissues of two or more teeth, and the number of teeth in the affected arch is usually less than one. It can be unilateral or bilateral. $^{1}$ Prevalence of bilateral fused teeth is reported to be $0.1 \% .^{2}$

An eagle's talon, or talons cusp, appears as an extra cusp on anterior teeth. It may affect single or multiple teeth. ${ }^{3}$ Prevalence of talon's cusp is reported to be between 0.04 and $10 \%$ in the English literature. $^{4}$

A 10-year-old boy presented to the clinic with large lower teeth (figure 1). On intraoral examin-

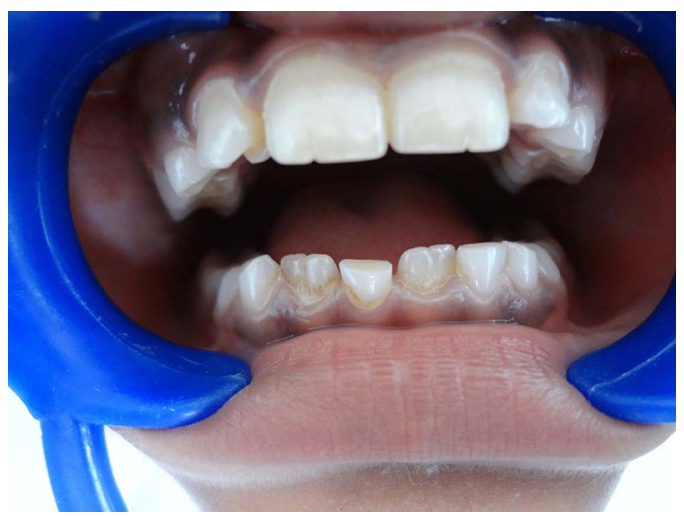

Figure 1 Intraoral photograph showing bilaterally fused mandibular central and lateral incisor.

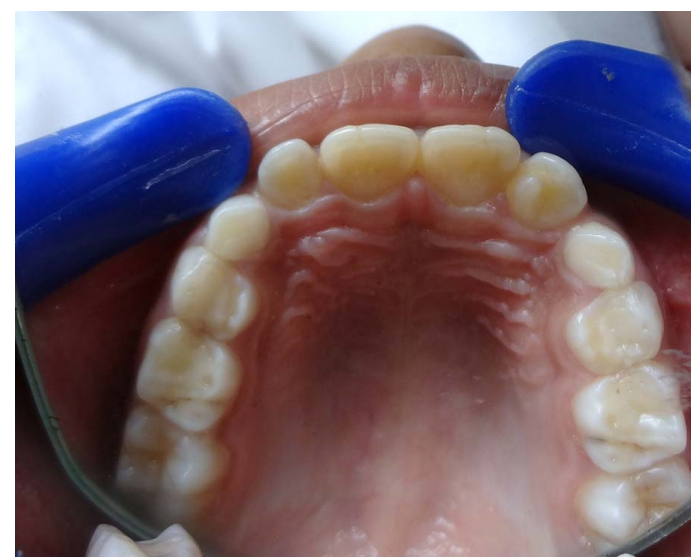

Figure 2 Intraoral photograph showing presence of dens evaginatus in relation to maxillary right lateral incisor. ation, 31 and 41 were found to be larger than normal. A groove was seen in the centre of the crown suggesting incomplete fusion of the permanent mandibular central and lateral incisor. A retained deciduous mandibular incisor was seen in between the permanent mandibular fused incisors. In addition to fusion, dens evaginatus (talon's cusp) was found in relation to maxillary right lateral incisor (figure 2). Orthopantomogram and intraoral periapical radiograph confirmed the fusion and talon's cusp (figures 3 and 4A, B). Maxillary central incisors showed presence of mammelons, which can be confused with a geminated tooth (figure 1).

The patient was advised extraction of the retained deciduous mandibular incisor followed by orthodontic treatment, which his parents were unwilling to allow. This concomitant occurrence of fusion and dens evaginatus is very rare.

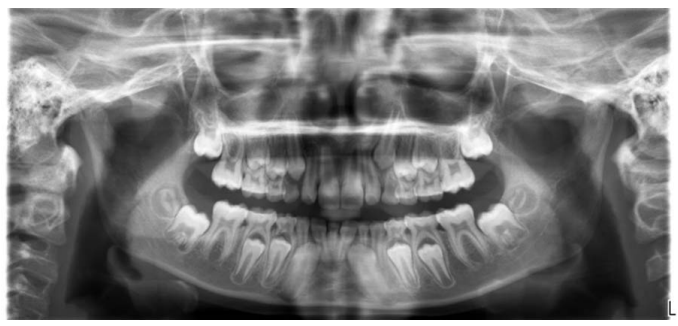

Figure 3 Orthopantomogram showing concomitant occurrence of bilaterally fused mandibular central and lateral incisors, and dens evaginatus in maxillary right lateral incisor.

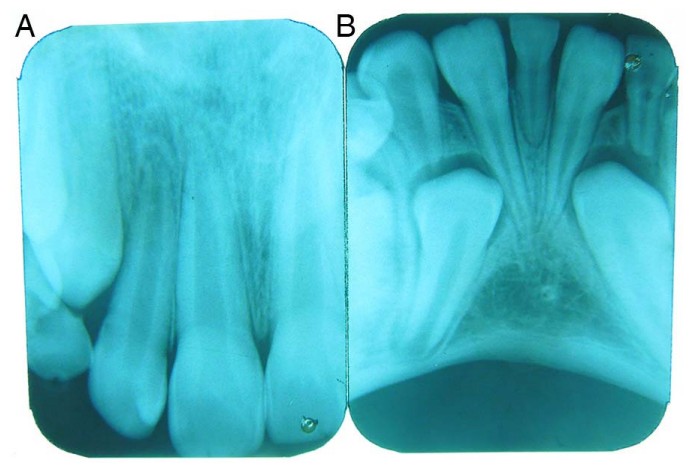

Figure 4 (A) Intraoral periapical radiograph showing talons cusp in maxillary right lateral incisor. (B) Intraoral periapical radiograph showing fusion of mandibular central and lateral incisors. 


\section{Learning points}

- A careful observation and appropriate investigations are required to diagnose this condition and to institute treatment.

- An early diagnosis and management of a talon's cusp is important, in order to prevent complications such as occlusal interference, compromised aesthetics, caries and periapical pathologies, as well as periodontal problems.

Twitter Follow Rachappa Mallikarjuna at @rachappa
Competing interests None declared.

Patient consent Obtained.

Provenance and peer review Not commissioned; externally peer reviewed.

\section{REFERENCES}

1 Pindborg JJ. Pathology of the dental hard tissues. Philadelphia: W.B Saunders Co, 1970:47-55.

2 De Siqueira VC, Braga TL, Martins MA, et al. Dental fusion and Dens Evaginatus in the permanent dentition: literature review and clinical case report with conservative treatment. J Dent Child (Chic) 2004;71:69-72.

3 Hegde KV, Poonacha KS, Sujan SG. Bilateral labial talon cusps on the permanent maxillary central incisors: the report of a rare case. Acta Stomatol Croat 2010;44:120-2.

4 Tulongolu 0, Cankala DU, Ozdemir RC. Talon's cusp: report of four unusual cases. J Indian Soc Pedod Prev Dent 2007;25:52-5.

Copyright 2015 BMJ Publishing Group. All rights reserved. For permission to reuse any of this content visit http://group.bmj.com/group/rights-licensing/permissions.

BMJ Case Report Fellows may re-use this article for personal use and teaching without any further permission.

Become a Fellow of BMJ Case Reports today and you can:

- Submit as many cases as you like

- Enjoy fast sympathetic peer review and rapid publication of accepted articles

- Access all the published articles

- Re-use any of the published material for personal use and teaching without further permission

For information on Institutional Fellowships contact consortiasales@bmjgroup.com

Visit casereports.bmj.com for more articles like this and to become a Fellow 